\title{
WITH ALICE
}

by

Delphine Lewis

Bachelor of Fine Arts, Concordia University, 2013 - 2016

\author{
A thesis \\ presented to Ryerson University \\ in partial fulfillment of the \\ requirements for the degree of \\ Master of Fine Arts \\ in the program of \\ Documentary Media
}

Toronto, Ontario, Canada, 2019

(C) Delphine Lewis, 2019 
I hereby declare that I am the sole author of this MRP. This is a true copy of the MRP, including any required final revisions.

I authorize Ryerson University to lend this MRP to other institutions or individuals for the purpose of scholarly research.

I further authorize Ryerson University to reproduce this MRP in photocopying or by other means, in total or in part, at the request of other institutions or individuals for the purpose of scholarly research.

I understand that my MRP may be made electronically available to the public. 
With Alice, Master of Fine Arts, 2019, Delphine Lewis, Documentary Media, Ryerson University

\begin{abstract}
At the age of fourteen, Alice began exploring the frustrations she faced as an adolescent, an artist, and a feminist - through her artistic practice. With Alice is a portrait of my cousin Alice, exploring her ever-shifting identity through painting and performance over a two-year period.

Alice's admiration for female characters that appear in 1930s, 40s and 50s films compelled her to paint women of these eras. The paintings blend images of herself with actresses she idolizes. In borrowing and re-working their images, Alice personifies aspects of her own personality inspired by these icons.

The photographs in With Alice portray Alice in her creative process, shaping her artwork and herself. In the formal portraits, Alice poses consciously for the camera, performing the women she paints. In participation with one another, we have created portraits of her own embodied icons.
\end{abstract}




\section{Acknowledgments}

First and foremost, I would like to thank my supervisor, Don Snyder, and my secondary advisor, Sara Angelucci, for their continued support, guidance, and invaluable insights throughout the development of my thesis.

I would also like to acknowledge associate professor, Gerda Cammaer, for encouraging me to follow my instincts.

Ruth Kaplan, thank you for inspiring my work and helping me make sense of my images in sequence.

I am extremely grateful to my participant, cousin, and close friend, Alice Ackerman. Thank you for sharing your world and artistic practice with me. To Andrea Most and Alan Ackerman, I am moved by your generosity in welcoming me into your lives with open arms.

Finally, Camille Gueymard and Brian Lewis, I am deeply appreciative for your unconditional belief in me. 


\section{Table of Contents}

Introduction

Getting to Know Alice

Subject and Rational

The Impetus Behind With Alice

Project Description

With Alice

Methodology

I. The First Story

II. The Second Story

Documentary Relevance

I. Performing for Oneself

II. Performing with Others

III. Practice-Based Research and Participation with Family

IV. Tableau Photography: Exploring Narrative in a Single Image

Conclusion

Appendix

Bibliography 


\section{Getting to Know Alice}

In October 2017, during my first semester in the Documentary Media MFA program at Ryerson University, I produced a written photographic narrative of an afternoon spent with my fifteenyear-old cousin, Alice. I had just moved to Toronto, and we barely knew each other. This experience marked the beginning of our growing relationship as cousins and as young women in conversations with one another about our artistic practices. This non-fiction narrative ultimately laid the foundation for my thesis production, With Alice.

The air is thick with the smell of Thanksgiving. Alice and I have been tasking with baking the apple crumble. I don't know my way around her kitchen, so I dictate the ingredients while she weaves around her parents, sifting through various cupboards and drawers. Reunited around the mixing bowl, we slice apples, mix cinnamon with lemon juice and brown sugar, grind oats and nuts to make flour, then carefully layer them into a baking dish. We slide it in the oven.

Task completed, we both look at the clock. We still have time before dinner: "Want to garb your camera? I'll show you how to load film." Alice smiles, which makes me smile. She runs upstairs to grab her equipment and meets me outside, still drenched in the smell of apples and pumpkin. We walk slowly against the wind toward my apartment, two blocks away. I've promised her a couple of rolls of expired black and white film. She's eager to learn to use her grandfather's camera, and I'm eager to know more about her and her work.

We climb three flights of stairs to my apartment. It's a mess, so I apologize. She doesn't mind and confesses that her room is even messier. I forget that I'm talking to a teenager. She walks 
around the 300 square feet and says, "This is all I would need. Just enough space for me, and enough space to do my work. Something cozy. " I look back at her as I pull film out from the only drawing in my half-sized fridge. I sort through the black and white rolls, eventually finding a few that aren't too old: “They've been in the fridge for a while, but we'll see how they turn out." She nods and slips the film into her pockets as we make our way out the door. This time, we take the fire escape, a steep metal staircase spanning three floors on the left side of the building. She doesn't flinch, but most people do.

She's taking me to a park nearby. It's late afternoon and still warm. We sit at the last picnic table in the sun to go over the basics: ISO, shutter speed, aperture, and depth of field. She's heard it all before, but wants a reminder. I show her how to load a roll of film, then pass the camera over. She takes her turn. It's not difficult, and she does it with ease. I tell her the story of my first roll: "I had gone to the countryside for the weekend and had taken what-I thought would be-amazing images. But as is turned out, my roll hadn't caught, and I hadn't recorded anything." We both laughed.

Camera around her neck, Alice is ready to shoot. We decide to walk around the neighborhood so that she can practice. We're both looking for images, scanning left, right, up, and down. We pass decrepit houses, and she starts taking pictures.

While I encourage her to explore my medium, I can't stop thinking about her work. The first time I encountered it was in her parents' basement, where my dad and I were staying for a few days while we searched for an apartment in Toronto. A large-scale self-portrait drawing hung on the 
wall: an honest image of herself, void of insecurity, self-doubt, or self-consciousness, rebelling against three emotions I typically associate with mid-adolescence.

The more I spent time with her, the more I began to understand the complexity of her work: girlhood, womanhood, and feminism. The more we speak, the more I begin to realize that she's closer to who I am today than to who I was at her age, eight years ago. She's now part way through her roll. We turn left into an alleyway, where Alice takes a photograph of a broken window and the driveway across from it. I also take a photo of the broken window with my phone, then one of her taking a photo. As I follow her back up the alley, I think about how I was also fifteen when I developed a serious interest in analog photography. Spotting a carwash, we cross the street. There's a blue Mini-Cooper in the parking lot next to a rotting sign. Alice snaps a photo.

Just as we pass a diner, Alice asks, "Can you tell me more about the project? You've told me before, but let's go over it again." A few weeks ago, she had agreed to participate in a photography series in which I would capture her artistic practice as a mid-adolescent who's interested in exploring her feminist identity. I tell her more about how I imagine the project's beginnings, and she tells me she's excited about it, and that it will be nice for her to have a documentation of her evolving work over the course of the next two years. From fifteen to seventeen, a lot is bound to change.

It's getting close to dinner time, the sun it setting, and we both need to change out of our clothes that are still sprinkled with flour and caramelized sugar. Alice has the last quarter of her roll to 
shoot. She photographs flowers, a fire escape, vines growing on houses, and a small fan left at the end of her neighbor's driveway labeled, “Broken. Take for parts.” We laugh, wondering which parts could be salvaged from a Cool Works fan. Just before we get to her house, she takes her last image: a sad-looking gargoyle. We part ways, and I head to my apartment to clean up.

I walk two blocks to my apartment and jog up the three flights of straights once again. While I change my clothes, wash my face, and attempt to tame my hair that's been knotted by the wind, I keep thinking about our project. Twenty minutes later, I head back to her house with a list of questions I'd like to ask her, and with vivid visualizations of the images we could create together.

Note: Copies of the photographs taken that afternoon can be seen on pages 5 and 6 of With Alice in Four Parts. 


\section{The Impetus Behind With Alice}

My practice has always been rooted in notions of identity, intergenerational relationships among family members, and sisterhood. During my undergraduate degree in fine art photography, I produced a portrait project, Sasha, which captured images of my younger sister in her high school. These were carefully composed images that revisited my own experiences of alienation and social pressures during adolescence. Through the act of posing and directing my sister, I studied the similarities between both of our emotional states, and difficulties, at the age of sixteen. With Alice is an extension of this, but with one important distinction: while I turned my lens to look at mid-adolescence in Sasha, With Alice functions as a dialogue with my participant focused on her own practice of exploring her identity. The foundation of With Alice is not built on the similarities we share, but rather, Alice's unique approach to representing herself through performance, and photography.

New to Toronto in 2017, I was welcomed into the lives and home of my relatives, the Ackermans, and quickly became a regular guest at their Shabbat dinners. This is where I began to spend time with fifteen-year-old Alice. Beginning her second year at the Etobicoke School of the Arts, Alice's artistic practice was rapidly expanding from drawing, to painting, to sculpture, installation, and performance. As we spent time together, our conversations often turned to her artwork and to mine. With Alice began through an intuition that Alice's artistic practice, and the relationship that we were developing, would be worth documenting.

With a background in portrait photography and a growing interest in documenting adolescence, I admired Rineke Dijkstra's painterly beach portraits of adolescents, Lauren Greenfield's 
expressive images of young girls and teens struggling to attain ideals of feminine beauty and behavior in Girl Culture, and Petra Collins' dreamlike photographs of her adolescent sister performing dramatized scenarios at home and at school. In retrospect, as I spent more time with Alice and approached the culmination of my thesis project, I noticed that these photographers, whose work has been foundational to my own practice, tended to capture narrow perspectives of the adolescent experience based on awkwardness, insecurity, vulnerability, and a desire to conform. The portrayals of their participants, regardless of intention, lacked multidimensionality and nuance that extended beyond adolescent tropes.

In With Alice, it has been my responsibility and challenge to showcase a complex portrait of Alice's identity through sequenced images and stand-alone portraits. What fascinates me about Alice is her self-assuredness and charisma, qualities I attribute to a genuine acceptance of herself, born through her willingness and desire to shape and explore her identity through her artistic practice, independently and in resistance to social pressures and group mentality that loom within her social circles. With Alice captures Alice exploring the self, for herself. 


\section{With Alice}

With Alice is a character portrait of my cousin Alice Ackerman, who from fifteen to sixteen, negotiates the obstacles she faces through her visual art practice. Over a two-year period, this has led her to explore her ever-shifting identity through painting and performance. At the core of this project are notions of participation, performance, and image-making, which are explored through three sections of visual materials. Together, images of Alice "in process," portraits of "embodied characters", and With Alice in Four Parts — a zine that outlines the production of With Alice chronologically_ present a multifaceted representation of Alice, and our relationship as artists and cousins.

The portraits of With Alice present Alice in two states of performance. The first is Alice as a young woman and artist during time off at home, between classes at school, and as she prepares and produces artwork, compelled by the performative nature of adolescence to participate in my documentation. These "in process" images highlight our growing relationship, and moments we've shared over the past two years during the conceptualization, preparation, and production of With Alice. In the gallery space, they are presented as $11 \times 14$ inch prints arranged in a sequence of triptychs, diptychs, and stand-alone images. These are naturalistic portraits, not candid images. They blend both traditions of candid and staged photography, always hinting at Alice's awareness and acknowledgment of my presence behind the lens.

The second section of visual materials is the portraits of "embodied characters". With a profound appreciation for 1930s, 40s, and 50s films, Alice began an ongoing series in which she paints portraits of women that blend images of herself with characters played by actresses she admires, 
such as Judy Garland, Ava Gardner, Lucille Ball, and Mae West. Alice carefully, and considerately, crafts these portraits to personify her ever-shifting personality, each one of them highlighting a quality, such as bravery or glamour, that together reflect facets of her complete identity. In my photographic portraits of Alice's "embodied characters", she becomes the women that she paints — becomes her own icon — as a means of exploring her identity, as well as claiming agency over her representation. Here, again, Alice poses for herself and for me. These are presented in the exhibition as framed 30x38 inch prints without glass, to reference Alice's own paintings of women that these portraits reference.

The final section of visual material, With Alice in Four Parts, is a booklet that chronicles the evolution of With Alice in its several iterations, my experience of working in participation with Alice, and Alice's own documentation of her work on social media. Importantly, the zine includes a few of Alice's paintings of women, paired with their fictional biographies. This allows Alice's artwork to enter into the gallery space in conversation with my own images. With Alice in Four Parts reaffirms again the importance of our relationship that grew in conjunction with With Alice.

In dialogue with one another, these three visual elements - the "in process" images, "embodied character" portraits, and Alice in Four Parts — create a dynamic portrait of a mid-adolescent artist, and raise important questions about the relationship of the documentary photographer with the participant, viewership, and the nature of documentary truth. 


\section{Methodology}

Following Alice's shifting artistic trajectory, With Alice has taken up significantly different iterations, based on two individual stories: Alice's feminist identity expressed through her visual art practice, and Alice's process of self-exploration through painting and performance. Yet, despite the project's transformations, one thing has remained consistent: the ability Alice and I share to work in parallel with one another. The most challenging and rewarding part of With Alice has been to allow the core focus of my project to shift as Alice's interests and work changes. This willingness to adapt, to accept the inevitable changes in a participant's interests, and to reconsider the purpose of one's work, is in fact at the core of documentary making, and central to my documentary practice. 


\section{The First Story}

When I first began working with her in September 2017, fifteen-year-old Alice Ackerman was exploring her feminist identity through a new medium. She was focused on creating experiential installations to respond to themes of censorship due to age discrimination, to address gender inequalities that exist in her religion, Judaism, and to critique female representation through a tangible medium that her viewers too could experience. Alice's growing feminist identity fueled her work, allowed her to gain a sense of belonging and community, and encouraged her to think and speak more critically, and freely, about the world around her.

During this time, for example, Alice was beginning to think critically about her religion. In response to the Bedeken, the Jewish religious tradition of veiling a bride during her marriage ceremony by the rabbi, she began working on a photography and painting series in which she captured herself standing in barren spaces, then painted on top of the images to obscure her face. Alice was preoccupied by the Bedeken as the act of a man veiling a woman in his presence, and its implications as a symbol of a bride's unapproachability to other men, of modesty, and submissiveness. While this project focused on critiquing a Jewish wedding tradition, Alice was expressing larger concerns about female alienation, male dominance, and oppression that her peers could also connect to regardless of religion.

Alice was the first young mid-adolescent I had encountered so strongly consumed by a desire to express her own feminist identity and concerns as a young woman, regardless of the resistance she faced at school and at home; like the difficulty of sharing projects critical of Judaism with her family, for example. In contrast to stereotypical depictions of adolescence in photography 
and film, Alice was on a complex journey of resistance and self-discovery, uninhibited by insecurity or self-doubt.

With Alice began as a documentation of how Alice used feminist engagement in her artistic practice to help her address the difficulties she faced as a mid-adolescent artist. In this first iteration, my research focused on Alice's feminist explorations as an example of one of the ways in which adolescents are becoming increasingly active in politics and feminism. Her feminist engagement began shortly after the rise of what is now thought of as fourth wave feminism, which began around 2012, and is marked by the use of internet-based platforms by adolescent feminists to fight against sexism and misogyny in everyday rhetoric. ${ }^{1}$ Early feminist engagement — by pre-teens and teenagers — has been attributed, in part, to the rise of online feminism. In the case of Alice, her feminist interests really took off at the age of fourteen when she discovered The Guerilla Girls, an online feminist artist collective, and began to follow their projects and activism through social media.

With the ability and privilege to access online platforms and social media accounts that encourage and feature young people speaking out against their own experiences of sexism, adolescents like Alice are fueled by a desire to be part of a movement that they relate to and can take part in easily online. While posting feminist quotes, testimonials, or protest images may have little impact on feminist progress as a political movement, the wealth of easily-accessible information about the basic principles of feminism, and the popularization of feminist engagement online, have encouraged young women like Alice to develop an awareness of subtle

${ }^{1}$ Ealasaid Munro, "Feminism: A Fouth Wave?" Political Insight 4, no.2 (2013): 22-25. 
forms of sexism, misogyny, and the larger patriarchal structures that continue to affect and restrict women. As well, they understand they are not alone, but part of a much larger community and movement.

Feminist cultural critic and columnist Susan Douglas (2010) writes about a new age of "enlightened sexism," most commonly referred to as post-feminism, which is characterized by satisfaction with the progress feminism has made so far, which creates an illusion of gender equality, and sways women to tolerate sexist stereotypes that no longer threaten them. ${ }^{2}$ Fourth wave feminism challenges this illusion.

However, fourth wave feminism is not itself without its critics. In her essay, \#Girlgaze: Photography, Fourth Wave Feminism, and Social Media Advocacy, Ruxandra Looft argues that feminist art platforms associated with the fourth wave claim inclusivity and aim to promote emerging female artists, but often fail to acknowledge the socio-economic disparities that restrict the participation of diverse readers and submissions online. ${ }^{3}$ Essentially, it too is exclusionary. Julie Zeilinger, on the other hand highlights its positive impacts in her book, A Little $F^{\prime} d U p$ : Why Feminism is Not a Dirty Word, which she wrote as an adolescent about the difficulties and advantages of early adolescent feminist engagement. Zeilinger describes the power of this movement that she experienced first hand, to change today's teenage experience by reducing girl-on-girl bullying, body image insecurities, and reversing mean girl stereotypes. ${ }^{4}$

\footnotetext{
${ }^{2}$ Susan Douglas, Enlightened Sexism: The Seductive Message That Feminism's Work Is Done (New York: Times Books, 2010).

${ }^{3}$ Ruxandra Looft, "\#Girlgaze: photography, fourth wave feminism, and social media advocacy," Continuum: Journal of Media \& Cultural Studies 31, no.6 (2017): 892-902

${ }^{4}$ Julie Zeilinger, A Little F'D UP: Why Feminism Is Not a Dirty Word (Berkley: Seal
} 
In conjunction with the outset of my research and the production of With Alice, Alice herself launched into a project in which she planned to build an installation to respond to the experience of having been prohibited from speaking about the gender pay gap in Canada at her summer camp. In this space, her voice would be amplified and played in a continuous loop so that her viewers, invited to enter her space, would not be able to interrupt her speech. Alice's next project, a few months later, was created in response to a reading of Anita Diamant's historical fiction, The Red Tent, given to her by her mother. Alice re-created the red tent from Diamant's book, where generations of women would gather to support one another. To reflect the disconnect, and at times lack of support she identified in her own intergenerational female relationships, Alice built her red tent large enough for only one person, and the birthing blocks, on which women would crouch to give birth, were stacked too tall to access comfortably. The final presentation of this work took place during her school's annual showcase and art sale, after which Alice realized that the power of her Red Tent was its ability to spark conversations with her mother about reconnecting and supporting one another. With both projects, Alice was attempting to respond to two of the deep concerns she was facing as a mid-adolescent young woman and feminist: censorship and a lack of intergenerational female support.

At this stage of my production, from Fall of 2017 through to the Summer of 2018, With Alice was composed of long-take and fixed-frame videos to document her life and practice. In the gallery space I had intended that my work would be projected as a two-channel video installation. I was planning to use these long-take fixed-frame videos to capture the performative

Press, 2012). 
and ambivalent nature of adolescence, allowing the constructed scenes we set up in front of the camera to unfold over time, and revealing the moments that exist between acts of performance. My principal film reference known for the long-take frames was the filmmaker, Chantal Akerman.

Much of the other visual material relevant to the production of this first iteration of With Alice was from documentary and fine art photographers who capture adolescence and youth culture. These included Rineke Dijkstra, who since the early 1990s has been photographing adolescents with a large format analog camera, who's long exposures demand engagement from her subjects who are almost exclusively looking into the camera's lens. Another important reference for With Alice has been Lauren Greenfield's photography book, Girl Culture (2002), which captures candid and composed images of women and girls from all over the United States to explore adolescence and body image.

As a narration for my video installation, I recorded discussions that Alice and I shared about her practice, her identity, her feminist interests and concerns, as well as my own. This dialogue was intended to act as an example of the way two young women, at different stages in their lives and artistic practices, could support and work in participation with one another.

In the final installation of With Alice I had planned to combine both of our works into the gallery space. My fixed-frame video would be installed within Alice's experiential installation. The most applicable example of this style of installation is seen in Tracey Emin's work, in which she exhibits appliquéd names of the people she shared a bed with over thirty years in a small tent on 
the gallery floor. ${ }^{5}$ The audio recordings of our conversations would narrate the events captured, and attempted to provide constructive discussions between two young women who create work that examines and critiques their social environments.

This first story documented two young artists, Alice and myself, helping one another in our processes of creation: I was helping Alice build an experiential installation, and in turn, Alice was helping me create my final thesis installation through participation and discussion. In participating in the act of creation together, I hoped we would be able to unpack and document the complexities of Alice's feminist identity, and how she used it to amplify her voice in her artwork.

Alice is now seventeen years old and her evolving artistic practice is no longer firmly rooted in feminism; however, this first story is important to acknowledge. Feminist engagement has been instrumental in encouraging Alice to express herself openly and regardless of resistance, and has also been the foundation on which our relationship, and With Alice, was built.

\footnotetext{
5 Tracey Emin, "Tracey Emin Exhibited at the Saatchi Gallery," Saatchi Gallery, https://www.saatchigallery.com/aipe/tracey_emin.htm.
} 


\section{The Second Story}

In response to Alice's shifting interests and artistic practice, With Alice has undergone an important transformation. During the summer of 2018, Alice's focus moved from experiential installations back to painting, the medium in which she first began her practice, to express herself artistically and explore her identity. With a profound appreciation for 1930s, 40s, and 50s, films and novels, Alice paints portraits of women that blend images of herself with actresses she admires, such as Doris Day and Mae West. These paintings express qualities such as confidence or timidity, which together reflect a picture of her complete identity. Through dress and performance, Alice embodies the women she paints and carefully considers the ways in which she expresses and represents her identity. Alice also regularly uses these paintings as references when she dresses, borrowing their appearance to fuel her mindset for that day.

One of the women Alice has painted is the fictional persona Lucille Brennan, inspired by Ava Gardner's performance of Justice Laverne in Show Boat (1951), Doris Day's character in Love Me or Leave Me (1955), Ruth Etting, and Judy Garland. Alice describes Brennan as “A suave and classy jazz singer whose life is in shambles even though she has all the success and money in the world. [...] When she sings, all her past miseries seep out of her. She's beautiful and melancholic."

During a conversation about this process in its early stages, Alice shared that " $[\ldots]$ these characters are all part of me, but I'm still Alice. So, I have these kinds of alter egos while still being me. [...] How I dress myself that day is my alter ego of the day. [...] It helps me express

${ }^{6}$ Alice Ackerman (With Alice participant) in discussion with the author, March 2019. 
myself. It's just separate parts of me that I want to express larger than others. [...] It's not necessarily me changing my personality for the people I'm with, it's just which one of me wants to be there that day."7 Alice's portrait project marked the beginning of the second story that transformed With Alice. The core of Alice's work was moving away from exploring her feminist identity toward a precise method of exploring her multidimensional identity as an individual.

At the same time, in September 2018, I became hesitant to continue presenting Alice as an example of the ways in which young women are engaged in feminist discourse. Over the course of our discussions, it became increasingly difficult to clearly define Alice's notion of feminism beyond a desire to attain equal pay and equal rights between women and men. I perceived growing tensions between the ways in which Alice chose to speak about her feminine identity in relation to her feminist identity, at times confusing the two. Alice's discourse about feminism was, understandably, reflexive, yet full of complexities and contradictions.

Alice had launched into a winding journey of self-discovery and I was confronted with a difficult ethical dilemma: exposing my participant to unfair criticism concerning her feminist discourse. Although Alice has an incredible determination to express herself freely regardless of the resistance she experiences from adults responding to her work, it was my responsibility as the documentary-maker to avoid creating a project, that when presented to others, had the potential to echo Alice's experiences of being misunderstood or dismissed due to her age. The first iteration of With Alice became restrictive for both Alice and myself. Alice's interests were changing, and so I allowed my thesis to evolve with her.

${ }^{7}$ Ibid, June 2018. 
As this second story revealed itself to me in the Fall, it became clear that With Alice had to undergo an important restructuring. I needed to expand With Alice to encompass notions of representation, performance and tableau photography, female iconography, and the complex relationship between documentarian and participant. With this new approach, I called my very medium into question: without the need to document experiential installations, the video installation I was creating would fall short of what I hoped to capture. Returning to analog photography to document Alice's life and practice was the project's natural progression.

Today, With Alice is a character portrait of Alice, a sixteen-year-old artist, who through painting, photography, and performance, explores her identity. With Alice is made up of photographic portraits of Alice in process - moments at home and at school when Alice is preparing herself for her performative portraits — and formal portraits of Alice's "embodied characters" reenacting her paintings. With Alice captures Alice in two states of performance that come naturally to her: as a mid-adolescent artist driven by the obstacles she faces posing for my camera, and as the personified women she paints, posing both for herself and for me.

Moving away from a video installation also meant letting go of Alice's paintings, on which I planned to project my work. But with my photographs of Alice's "embodied characters" at the core of With Alice, I felt it was important to find a way to incorporate them in the work without physically including them in the gallery space. At the same time, it was also imperative that I retain full authorship of the exhibition by highlighting my photographs as their own entity and not as an extension of Alice's work. 
With Alice is not a collaborative project, but rather, created through a participatory practice. To clearly delineate my own work from Alice's, I created a zine, With Alice in Four Parts, which invites viewers to gain a deeper understanding about the production and evolution of With Alice. This zine functions as additional information to the project, providing images of With Alice's first iteration, my own notes detailing the process, and also photographs of Alice's painted women with descriptions of each character's origin. With Alice in Four Parts allows Alice's voice to enter the work in dialogue with my own images as a dynamic representation of her practice. 


\section{Documentary Relevance}

At the core of With Alice is the notion of representation. My photographs reveal how I see Alice, how she sees herself, and ultimately, they are responsible for the ways in which others will perceive Alice. In the early stages of my research, I revisited the collection of essays that has been foundational to my photography education and to the development of my practice, The Photography Reader, edited by Liz Wells.

As in fine art photography, documentary photographers chose their subjects, frame their images, and sequence their work to present clear narratives to their viewers. In her chapter, Photography Within the Humanities, Susan Sontag writes: "[...] For the photographer, the world is really there; $[\ldots]$ and in fact, more interesting when seen through the camera than when seen with the naked eye or with real sight. The camera $[\ldots]$ enables you to transform the world, to miniaturize it. ${ }^{\prime 8}$ In With Alice, the camera does in fact enable me to see: in front of my lens Alice embraces her performances, transforms, and becomes her own icon, moving viewers to consider questions of female representation, performance, adolescent identity, and participatory practices in photography.

In With Alice, I work consciously with the subjective nature of photography to inform my project. This is a representation of Alice's life, not an objective documentation of it. In fact, the strength of my thesis lies in what happens between Alice and myself in the act of image making. With her participation, I create visual representations of Alice's fantasies about facets of her idealized self. In these portraits, two young artists gaze at each other, both actively aware of the

\footnotetext{
${ }^{8}$ Susan Sontag, "Photography Within the Humanities," in The Photography Reader, ed. Liz Wells (New York: Routledge, 2003), 62.
} 
camera's role in facilitating this exchange. During subsequent research, I looked primarily to photography curator and writer Charlotte Cotton, whose book, The Photograph as Contemporary Art, has allowed me to situate With Alice within traditions and methodologies of contemporary performative, participatory and tableau photography. 


\section{Performing for Oneself}

Defined by Thomas Waugh, presentation performance in film is the act of "performing an awareness of the camera [...]," and "[...] presenting oneself explicitly for the camera [...]." By using techniques of staging and presentational performance in the portraits of With Alice, I acknowledge the performative nature of the adolescent experience. Perhaps the most significant and relevant photographic references in relation to With Alice can be found in the works of photographers Suzy Lake and Cindy Sherman, who consistently use presentational performance to address notions of viewership, performance, and female representation in front of their lens.

Following the 1967 Detroit Riot, Detroit-born artist and activist Suzy Lake immigrated to Montreal. Fueled by her political engagement and experiences of the civil rights and anti-war movements in the United States, Lake began examining female inequity through photography. In her notable slideshow project, On Stage (1972-1974), Lake photographed black-and-white selfportraits in which she performed conventional patterns of behavior and dress practiced by professional models at the time. On Stage creates a space in which she projects and criticizes female iconography in the context of fashion photography and explores the tensions between identity and agency within the limitations of societal expectations of women, and in turn, the self-expectations that women internalize and perform. ${ }^{10}$

\footnotetext{
${ }^{9}$ Thomas Waugh, The Right to Play Oneself: Looking Back on Documentary Film (Minnesota: University of Minnesota Press, 2011), 76.

${ }^{10}$ Suzy Lake, “Introducing Suzy Lake,” in Introducing Suzy Lake, ed. Georgiana Uhlyarik (London: Black Dog Publishing, 2015), 15.
} 
In a lecture during the ArtsEverywhere Festival in Ontario in 2017, Lake described On Stage as “[...] intended to be a critique of women's representations in the media," hoping that "[...] the mimic was a strategy to invert the imposition of who we were and who we were supposed to be."11 Yet, "when On Stage was first shown, it was met with accusations of narcissism. [...] The problem of the artist being female, and seen as the subject matter in the work, obscured the content. Without realizing the persistence of the male gaze, I wondered what I had actually done to mislead my audience. [...] The problem was that there was an aesthetic plurality of work by women at the time, but assumptions about what feminism was closed critical discourse [...]. [...] My own portrait work of this period certainly taught me that the search for one's voice and one's self often takes place in the dynamic of resistance."12 This portion of Lake's lecture brings up an important component of With Alice: the driving force behind Alice's early work on feminism was foundational to her practice and led her to the act of performing her own characters that mimic female iconography of 1930s, 40s, and 50s film stars.

Similarly to Lake's, Alice's artistic practice began as an act of resistance through which she could express and criticize her experiences of censorship and female inequity, and explore her developing feminist identity. But through this process of self-exploration, Alice met resistance from adults and peers who expected her to possess a clear-cut and intersectional definition of feminism. As a young woman and artist with an interest in exploring female identity, I understand the difficulty and complexity that Alice faced in attempting to answer these questions to the best of her ability. In hindsight, Alice's shifting interests, from a focus on expressing

${ }^{11}$ ArtsEverywhere, "Suzy Lake on the Politics of Gender, the Body, and Identity," ArtsEverywhere, 2017, https://artseverywhere.ca/2017/05/25/suzy-lake-politics-gender-bodyidentity/.

${ }^{12}$ Ibid. 
feminist concerns to an exploration of personal identity, was a result of this hurdle. Rather than framing her work within existing feminist discourses, Alice looked inward at herself and her own identity as a young woman, unbound by terminology and convention.

There are clear parallels between Alice's work and Lake's enactments in On Stage to criticize female representation in media. In the embodied portraits of With Alice, Alice represents iconic imagery of women from 1930s, 40s, and 50s films that she consumes regularly. Alice embraces this traditionally feminine, glamorous, and sultry iconography. What is most interesting about Alice's performances are her intentions, which are different from those of Lake. Rather than projecting images of women crafted for and consumed by a male audience, her performances are unequivocally created for herself. While these images present Alice's fantasies about idealized versions of herself that are often in line with stereotypical imagery of women, their sole purpose is to explore, enact, and express various facets of her identity. In contrast to Lake, then, Alice is not resistant to tropes of female representation, but instead she celebrates them.

As with Lake's work, my own portraits of Alice's "embodied characters" bring up questions concerning the male gaze. In mirroring old Hollywood aesthetics and pose in my portraits, could Alice and I be reinforcing conventions of female iconography, and in turn, be satisfying the male gaze? In her essay, Visual Pleasure and Narrative Cinema, Laura Mulvey considers how tropes of female representation in cinema reinforce patriarchal language. She states that it was in fact 1930s, 40s, and 50s, Hollywood films that popularized cinematic visual languages rooted in the objectification and eroticization of women dominant under the patriarchal order ${ }^{13}$ However,

${ }^{13}$ Laura Mulvey, "Visual Pleasures and Narrative Cinema," in Film Theory and Criticism: 
Mulvey also insists that there is power in "[...] leaving the past behind without rejecting it, transcending outworn or oppressive forms, $[\ldots]$ in order to conceive a new language of desire." 14 I would argue that in appropriating old Hollywood icons, Alice allows them to enter her work in dialogue with her own contemporary expressions of her female, and feminist, identity, and these are the moments I capture in my portraits. With a genuine appreciation for the aesthetic qualities of femininity expressed in old 1930s, 40s, and 50s films, she consciously performs tropes of female representation and derives power from them, My portraits of "embodied characters" are sincere expressions of Alice's powerful self-confidence. Here, Alice is not "the woman as icon, displayed for the gaze and enjoyment of men," "but rather the "active controller of the look" demanding that we look at her expressing herself. My portraits demand that viewers reconsider the ways in which they interpret images of young women.

Another significant photographic reference in relation to With Alice is Cindy Sherman's project, Untitled Film Stills. Produced between 1977 and 1980 in New York City, Sherman's Untitled Film Stills is a series of black-and-white photographs in which she photographs herself dressed and performing as female film characters from 1950s and 60s Hollywood, film noir and art house films. ${ }^{17}$ In The Photograph as Contemporary Art, Charlotte Cotton describes Sherman's work as a prime example of postmodern photography, characterized by its " [...] appropriation of and

Introductory Readings, ed Leo Braudy and Marshall Cohen (New York: Oxford UP, 1999), 835 .

14 Ibid.

15 Ibid, 840 .

${ }^{16}$ Ibid, 840 .

${ }^{17}$ MoMA, "Cindy Sherman: Untitled Film Stills 1977-1980," Museum of Modern Art, https://www.moma.org/learn/moma_learning/cindy-sherman-untitled-film-stills-1977-80/. 
pastiche of generic types of visual images." ${ }^{, 18}$ The power in Sherman's Untitled Film Stills series is " $[\ldots]$ the ease with which each feminine 'type' are recognizable. [...] And is therefore, a demonstration of the argument advanced by feminist theory that 'femininity' is a construction of cultural codes and not a quality that is naturally inherent or essential to women.. ${ }^{19}$ In dialogue with my zine, With Alice in Four Parts, the portraits that make up With Alice also evoke powerful narratives about each of her characters, gender performance, and the multidimensionality of identity.

Like in my portraits of Alice's “embodied characters," Sherman's images are carefully composed and referential, but they remain somewhat ambiguous. ${ }^{20}$ Sherman offers her viewers one side of a complex story: images of women whose gaze is fixed, often suspiciously or in a terrified manner, toward the camera or toward an off-screen instigator or observer. Her photographs capture female characters alone, but always imply the presence of someone else. If no one is watching, who is there to perform to?

This question is particularly relevant in Alice's case. The act of embodying the characters she paints is a practice of self-reflection and exploration. Is Alice, who is always aware of the camera, gazing toward the camera as a means of gazing at herself? And where does that put me, the photographer? Mulvey's describes cinema as satisfying our desire to indulge in the pleasure

\footnotetext{
${ }^{18}$ Charlotte Cotton, The Photograph as Contemporary Art (London: Thames \& Hudson Ltd., 2009), 192.

${ }^{19}$ Ibid ,193.

${ }^{20}$ MoMA, "Cindy Sherman: Untitled Film Stills 1977-1980,” Museum of Modern Art, https://www.moma.org/learn/moma_learning/cindy-sherman-untitled-film-stills-1977-80/.
} 
of looking. ${ }^{21}$ The same can be said for photography. She maintains that imagery of women displayed for an audience traditionally function in two ways: as an "erotic object" for other characters, or for the spectator. ${ }^{22}$ This implies that "in herself, the woman has not the slightest importance." 23 In my portraits of Alice "embodied characters," Alice is the sole actor. Through my images, I allow her to perform self-indulgent fantasies. This self-indulgence, and Alice's awareness and acknowledgment of it, is in fact one of With Alice's greatest strengths, which actively resists the possibility of interpreting Alice's practice, and my portraits, as satisfying patriarchal expectations of female representation

While Sherman and Lake both played out female tropes as gestures of criticizing female representation and the male gaze, Alice's work is an homage to the actresses and the female characters she idolizes. In viewing my portraits of Alice's "embodied characters", we are gazing at expressions of her ideal self. With Alice pulls all of us - participant, photographer, audienceinto a multi-leveled but entirely ambiguous and subjective experience.

${ }^{21}$ Laura Mulvey, "Visual Pleasures and Narrative Cinema," in Film Theory and Criticism: Introductory Readings, ed Leo Braudy and Marshall Cohen (New York: Oxford UP, 1999), 836.

${ }^{22}$ Ibid, 838 .

${ }^{23} \mathrm{Ibid}, 837$. 


\section{Performing with Others}

With Alice practices a participatory documentary approach, defined by Bill Nichols in film as the mode through which the filmmaker rejects voice-over commentary, objectivity, and observational filmmaking, to "[...] become a social actor (almost) like any other." ${ }^{24}$ An important example of the participatory documentary mode in film is seen in Jean Rouch and Edgar Morin's film, Chronique d'un été (1961), whose opening scene coins the term 'cinéma vérité'. Rouch and Morin actively participate in their film through conversations with their friends and acquaintances over the course of a summer in Paris in 1960. They attempt to capture "film truth," which they define as being found in human encounters, rather than in facts. ${ }^{25}$ With Alice is within this tradition. My photographs are conversations and negotiations, and the truths which are discovered are deeper than mere observations, and perhaps more ambiguous. As with Rouch and Morin, the truths of With Alice exist in the relationship Alice and I have built through the moments we share creating images with one another.

Bill Nichols continues: in performative film, "an autobiographical note enters [...] that bears similarity to the diaristic mode of participatory filmmaking. Performative films give added emphasis to the subjective qualities of experience and memory that depart from factual recounting." ${ }^{26}$ Similarly to film, performance in contemporary photography encourages viewers to acknowledge the active involvement of an image's participant, and more importantly, the subjective gaze of its photographer.

\footnotetext{
${ }^{24}$ Bill Nichols, Introduction to Documentary (Bloomington: Indiana University Press, 2001), 116.

25 Ibid, 118.

${ }^{26}$ Ibid, 131.
} 
These images derive from the act of carefully composing and directing an event for the sole purpose of taking a photograph, which in turn, requires that "the act of artistic creation begin long before the camera is actually held in position, $[\ldots]$ starting instead with the planning of the idea. ${ }^{27}$ Here, the concept dictates the photograph. This process of creation, based in planning and conceptualizing for the realization of a coherent narrative, is also an essential characteristic of documentary-making. Yet, contemporary conceptual photography sets itself apart from traditional snapshot documentary photography in its determination to acknowledge the presence of the photographer as an explicit participant in the events that unfold in front of the lens.

With Alice is rooted in the tradition of photographers who depend on the participation and performance of their participants to create their images. These photographers - for instance, Hellen Van Meene and Evan Baden - use the performance of non-actors to dramatize real life. My own practice uses conceptual photography as a mode through which I can present a documentary subject. Performance through staged portraiture reveals intimate glimpses of Alice's internal world. Rather than to focus on capturing a candid "day in the life", With Alice demonstrates how the use of fictionalization, dramatization, and performance are effective modes of representing intimate truths: Alice's own understanding and visualization of identity, formalized through the participation of both subject and photographer in the process of imagemaking.

A consistent inspiration since the early stages of my production has been the work of Dutch photographer Hellen van Meene, who blends fact and fiction in portraiture. Since the mid-1990s,

${ }^{27}$ Charlotte Cotton, The Photograph as Contemporary Art (London: Thames \& Hudson Ltd., 2009), 121. 
van Meene has been photographing young girls and adolescents in unlikely, and often otherworldly, scenes. ${ }^{28}$ Her images are staged and carefully composed, but imply the feeling of looking into private and pensive moments in her participants' lives. Like my portraits of Alice's "embodied characters," van Meene's subjects perform a version of themselves for the camera. These are not naturalistic portraits of young girls and adolescents, but representations of her subjects as participant performers, complicit in the act of image making.

Cotton observes that the mystery in van Meene's images stems from her "[ $[.$.$] coupling of a$ conscious sense of what she wants to capture with a deliberate putting aside of her prepared 'script' and her photographing of what then spontaneously unfolds. Strategy here is about constructing an environment that draws the subject out, first through the photographer's choreography and then through the responses of the individual sitter. ${ }^{, 29}$ This approach is particularly relevant to With Alice's portraits of Alice "in process." While this section of visual material functions as a more naturalistic documentation of Alice's life, each image stems from a posed moment. My image-making process has three stages: identifying a potential image through an organic moment, asking Alice to freeze that moment, and then photographing the posed moment and allowing it to be broken by my participant. These images are far from candid photographs, but rather snapshots of Alice's life, played out before me.

Evan Baden also works with the participation and performance of his subjects in contemporary photography. In his series, Under the Influence, he examines American pop-culture viewership

\footnotetext{
28 "Helen van Meene," Guggenheim Museum, https://www.guggenheim.org/artwork/10235.

${ }^{29}$ Charlotte Cotton, The Photograph as Contemporary Art (London: Thames \& Hudson Ltd., 2009), 33.
} 
as a source of teen identity formation. Baden sought out adolescents to step into his frame and embody a celebrity of their choice, and together, they create images that are in direct dialogue with the tropes and stereotypes that are deeply engrained in pop culture images. ${ }^{30}$

For Baden, participating in the making of his images allows his models to "[...] be transformed into the very thing they admire and aspire to be; the very thing they have spent so much time looking at. Now, they too will be looked at." ${ }^{31}$ Through dress and performance, Baden's participants gain agency over the representation of their ideal self. However, by photographing the teenagers performing a version of what they idolize, Baden also allows the possibility of social critique and reflection to enter his work: what pop-culture references are adolescents drawn to, and what messages are they sending about dress, behavior, conformity, and material success?

As with Baden, in my portraits of "embodied characters," Alice has full agency over her dress and performance and plays out fantasies in which she physically, through sartorial choices and performance, becomes an ideal version of herself. At the same time, these portraits allow viewers to consider, and even question, Alice's ideals of female beauty and behavior through observing the carefully crafted dress and poses — often hyper-feminine - that Alice stages for the camera.

\footnotetext{
${ }^{30}$ Evan Baden, "Under the Influence," Evan Baden, 2013, http://www.evanbaden.com/underthe-influence-\%E2\%80\%93-201213.html.

${ }^{31}$ Ibid.
} 


\section{Practice-Based Research and Participation with Family}

I share with the photographers I have referenced a fascination with youth and adolescent behavior and performativity. But there is additional important dimension of With Alice: the relationship that Alice and I have developed as young artists, and as cousins, working together over a two-year period. Working on our practices in parallel with one another has been foundational to the creation of the portraits that make up this project.

My practice has always blended fact and fiction; fine art photography with documentary. When I first began working on With Alice it was a challenge to situate my project within research-based documentary work. However, through this creative process, I have realized that the research at the core of With Alice takes place in the moments that we spend together, and the conversations that we share as young artists and cousins. This is a project rooted in practice-based research, where knowledge is gained internally through our growing relationship, which is fueled by the process of image making.

In her essay, Image as Insight: Visual Images in Practice-Based Research, Julia Marshall considers the act of photographing as a mode of practice-based research, in the context of art education, as "[...] an exercise in knowledge construction: a process of coming to know." "32 To define practice-based research, Marshall looks to Australian artist and art theorist Graeme Sullivan, who qualifies practice-based research as " [...] an inquiry that is centered in creative practice where the artist uses image-making as the primary mode of exploration," that "[...] the

\footnotetext{
32 Julia Marshall, "Image as Insight: Visual Images in Practice-Based Research," Studies in Art Education 49, no.1 (2007): 24, https://www.researchgate.net/publication/234665454_Image_as_Insight_Visual_Images_in_Prac tice-Based_Research.
} 
creation of images is the primary mode of inquiry." ${ }^{, 33}$ Further, Marshall acknowledges Carole Gray’s and Julian Malins' definition, which recognizes practice-based research as a constructivist mode, characterized by being a "[...] reflective practice where the artistpractitioner shapes findings in the form of visual images to construct meaning." ${ }^{34}$ What sets practice-based research apart from conventional modes of research is the intent to re-frame existing knowledge rather than uncovering new information to "[ $[.$.$] transform perception: to$ change the way we see or interpret things." 35

Practice-based research is precisely what I have been engaged in over the course of the conceptualization, development, and production of With Alice. This project grows from important and revealing moments that Alice and I spend creating images together. It is from our conversations and actions in those moments that the knowledge of Alice's practice, the way she functions in her social circles, and how our relationship defines itself, are revealed. These moments encourage Alice's her personality, thoughts, and motivations to be expressed. Through my portraits, I interpret, capture, and represent that knowledge. Conceptualizing and photographing are my principal modes of inquiry.

Alice is my cousin, although someone I barely knew before my project began. It has been essential to the development of my thesis project and research to consider as well the work of photographers known for working with their own families, exploring notions of personal identity

\footnotetext{
${ }^{33}$ Ibid.

34 Julia Marshall, “Image as Insight: Visual Images in Practice-Based Research," Studies in Art Education 49, no.1 (2007): 25, https://www.researchgate.net/publication/234665454_Image_as_Insight_Visual_Images_in_Prac tice-Based_Research.

${ }^{35}$ Ibid.
} 
and family dynamics. Photographers Larry Sultan and Alessandra Sanguinetti, for example, use the acts of staging and photographing as tools through which they ask and answer questions about personal experiences and familial relationships. In their works, emotional truths live in the performances their family members deliver for their cameras.

The very first photographic series that drew me to portraiture with a focus on family relationships is Larry Sultan's ten-year long project, Pictures from Home. First published in 1992, Sultan's images act as character portraits of his parents, both retired, living in their home in Palm Springs. Blending staged and spontaneous moments together, his parents appear as nonactors playing themselves for their son's lens, as well as subjects at times unaware of Sultan's gaze. In an excerpt from the first print edition of Pictures of Home, Sultan explains that his work "[...] has more to do with love than with sociology, with being a subject in the drama rather than a witness. And in the odd and jumbled process of working everything shifts; the boundaries blur, my distance splits, the arrogance and illusions of immunity falters. [...] I realize that beyond the rolls of film $[\ldots]$, the demands of my project and my confusion about its meaning, is the wish to take photography literally. To stop time. I want my parents to live forever." ${ }^{36}$ While these images capture his parents, they also situate Sultan himself centrally within his performative narratives.

The portraits in Pictures from Home evoke feelings of being watched, and the photographer himself takes up the role of the onlooker. While actively participating in the creation of these portraits, there is a clear sense that without Sultan's presence, the drama of these mundane moments would be unremarkable and go unnoticed. Sultan captures emotionally charged

\footnotetext{
${ }^{36}$ Larry Sultan, "Pictures from Home: Statement/ History," Larry Sultan, http://larrysultan.com/gallery/pictures-from-home/.
} 
imagery that places his parents, their lives, and their family dynamics within larger conversations about the all-American family, the American dream, and mortality. He crafts images that carry "[...] the tricky balancing act between critical distance and emotional engagement, between empathy and voyeurism. ${ }^{\prime 37}$ Even in his most candid images, such as a photograph of his mother sleeping, Sultan insists that his parents and himself " $[\ldots]$ we co-conspirators. Just as I was secretly photographing, she was secretly awake. She felt me looking." ${ }^{\not 38}$ This effortless complicity, between photographer and participant is where the unmatchable potential of working within intimate relationships lives. This potential is one I explore in With Alice.

The portraits of Alice "in process" combine staged moments with candid environmental portraits of Alice's everyday life. Like Sultan, I am a social actor in With Alice who remains behind the lens. Whether Alice is looking directly at me, the camera, or away from me, these images depict a mid-adolescent artist steadily aware of the photographer's gaze. We are co-conspirators working in connection with one another to create effective and expressive representation of Alice's everyday life. When working with family, a lot can be at stake. Within the context of creating this documentary practice, it has been both challenging and rewarding to strike a balance between artist, image-maker, peer, and protective family member.

Alessandra Sanguinetti also photographs members of her family with a focus on childhood in her series The Adventure of Guille and Belinda and the Enigmatic Meaning of their Dream. This five-year long project based outside of Buenos Aires, Argentina, documents her two young

\footnotetext{
${ }^{37}$ Sean O'Hagan, "Pictures from Home by Larry Sultan review-When Mom and Dad Lived the Dream," The Observer, (2017): 39, https://search-proquestcom.ezproxy.lib.ryerson.ca/docview/1894228921?accountid=13631.

${ }^{38}$ Ibid.
} 
cousins, aged 9 and 10, and their relationship to one another. ${ }^{39}$ Encouraging the young girls to make their own "[...] decisions about how to represent themselves, often involving theatrical performance and dressing-up, ${ }^{, 40}$ and to play them out for the camera, Sanguinetti successfully illustrates the curiosity and inventiveness of childhood and the make-believe worlds her cousins craft.

In contrast to Sultan's photographs, "the role of the photographer [here] is one of recording or facilitating the girls' self-expression rather than as a choreographer of their representation." ${ }^{41}$ Sanguinetti insists that her cousins maintain agency over their own representation, even at a young age. In my experience during the production of With Alice, this process of encouraging performance, but ensuring your participant's authenticity in those performances, can lead to a meaningful and reciprocal relationship between the photographer and the photographed. But to find this balance, it is essential to acknowledge the importance of a participant's agency in front of the lens. Like in The Adventure of Guille and Belinda and the Enigmatic Meaning of their Dream, With Alice's portraits of "embodied characters" are in fact performances that speak to the way Alice demands to express herself and wants to be seen by others. Like Sanguinetti, my portraits facilitate Alice's agency over her own representation, without judgment.

Sanguinetti's second installment of this series, The Life That Came, is in slight contrast to her first, re-presenting Guille and Belinda as adolescents and young adults, and capturing moments

\footnotetext{
${ }^{39}$ Rollo Romig, "Off The Shelf: The Adventures of Guille and Belinda," The New Yorker, June 18 2010, https:/www.newyorker.com/culture/photo-booth/off-the-shelf-the-adventures-ofguille-and-belinda.

${ }^{40}$ Charlotte Cotton, The Photograph as Contemporary Art (London: Thames \& Hudson Ltd., 2009), 156.

${ }^{41}$ Ibid.
} 
of tranquility, playfulness, the realities of young motherhood, and their shifting relationships. In both works, Sanguinetti expresses themes of identity construction, performance, and imagination, intertwined with hints of the real world where performativity temporarily fades away. ${ }^{42}$ Similarly, in With Alice, Alice is photographed in many states of performance but also during transient moments of vulnerability; both states are equally part of Alice's ever-shifting identity. As With Alice, the works of Larry Sultan and Alessandra Sanguinetti function within a mode of practice-based research, which is cultivated through personal and familial relationships with their subjects. The projects are all narratively driven. This leads me to my final chapter, where narrative thrives: the tradition of tableau photography.

\footnotetext{
42 "Alessandra Sanguinetti," Women in Photography New York, https://www.wipnyc.org/past/2017215-2.
} 


\section{Tableau Photography: Exploring Narrative in a Single Image}

In contrast to photo-stories and series that use multiple sequential images, in tableau photography, "[...] narrative is concentrated into a single image: a stand-alone picture. [...] Tableau photography has its precedents in pre-photographic art and figurative painting of the eighteenth and nineteenth centuries [...]. It is important to think of contemporary photography's affinity to figurative painting as $[. .$.$] demonstrating a shared understanding of how a scene can$ be choreographed for the viewer so that he or she can recognize that a story is being told."43 To situate With Alice within the tradition of storytelling in contemporary photography, and reveal the power of the single photograph to tell a complex story, I have looked at several photographers who work in tableau photography to construct narratives: Jeff Wall, Tom Hunter, and Sarah Jones.

Tableau photography presents viewers with the possibility of understanding or constructing an insular narrative in a single image. In With Alice, the portraits of "embodied characters" are stand-alone portraits, each one of them telling unique stories about Alice's alter egos. These portraits, like tableau photography, reference painting. And even more, in With Alice they directly reference Alice's own paintings of the women she embodies.

Vancouver-born Canadian artist and leading contemporary tableau photographer Jeff Wall began his image-making practice in the early 1980s after working as an art historian for a decade. ${ }^{44}$ Wall's cinematic images reconstruct everyday moments and scenarios borrowed from his

${ }^{43}$ Charlotte Cotton, The Photograph as Contemporary Art (London: Thames \& Hudson Ltd., 2009), 49.

${ }^{44}$ Artnet, "Jeff Wall," Artnet, http://www.artnet.com/artists/jeff-wall/. 
personal experiences, art history, and fiction. Wall considers these tableaux "near documentary," which he explains are "[...] pictures whose subjects were suggested by my direct experience, and ones in which I tried to recollect that experience as precisely as I could, and to reconstruct and represent it precisely and accurately." ${ }^{45}$ While some of his images bear the illusion of having been candid, they are "[...] stylized just enough for us to suspect that [what we are looking at] is a choreographed event [...]. ${ }^{46}$ As Wall draws from his knowledge of art history and familiar iconography from fiction films, Alice employs the knowledge she gained through watching $1930 \mathrm{~s}, 40 \mathrm{~s}$, and $50 \mathrm{~s}$ films to inform the characters she creates. The women that she paints, and then embodies, are reinterpretations of the female archetypes she admires. In my portraits of “embodied characters," I construct tableaux, still moments in which viewers can read clues, through expression and sartorial choices, that point to Alice's old Hollywood references. In a single image, time, space, and narrative come together to bring each of these histories to life.

In reference to Victorian tableaux, Tom Hunter uses " [...] historical visual motifs $[\ldots]$ in a contemporary photographic subject $[\ldots]$ as a confirmation that contemporary life carries a degree of symbolism and cultural preoccupation parallel with other times in history [...]. ${ }^{, 47}$ In a photograph called The Way Home, a young woman appears lifeless, floating in a stagnant pool of water surround by brush. This image is a direct reference to John Everett Millais' 1852 painting,

\footnotetext{
${ }^{45}$ Ibid.

${ }^{46}$ Charlotte Cotton, The Photograph as Contemporary Art (London: Thames \& Hudson Ltd., 2009), 51.

${ }^{47}$ Charlotte Cotton, The Photograph as Contemporary Art (London: Thames \& Hudson Ltd., 2009), 55.
} 
Ophelia. ${ }^{48}$ This act of reinterpretation is closely tied to Alice's own practice of identity exploration through painting, photography and history.

For example, in one of my portraits, Alice plays the role of Ruby Grey, a woman she painted whose identity and appearance are inspired by Carol Forman's character, Sombra, in the 1947 black-and-white crime film, The Black Widow. While my images make more subtle connections to their historical references than Hunter's, my portraits of "embodied characters" function in two ways: Alice draws attention to the historical sources she references through her performance itself, and my photograph reminds viewers, through environmental clues in the décor of the interior spaces she occupies, that this is in fact a mid-adolescent artist playing out her fantasies. Simultaneously, these images transport viewers to both fictional and factual worlds.

Another similarity between Hunter's work and my own is his use of large-format analog technology to produce his images. While I work in medium-format, both media nod to the history of photography, to the tradition of posed portraiture, and to historically significant fashion photographers, for example Helmut Newton and Annie Leibovitz, whose editorial images produced through analog media weigh aesthetics and narrative of equal importance. In an era where digital technology in photography is convenient and at my disposal, the choice to work in medium-format analog photography for With Alice was intentional. In my practice, analog photography, especially in formats larger than $35 \mathrm{~mm}$, requires me to slow down and to make more considerate decisions about what I'm photographing. In With Alice, I often use long exposures to compensate for a lack of light in interior spaces. Because of this, Alice and I were

${ }^{48}$ Ibid. 
required to work symbiotically in our efforts to create vivid tableaux. This slower and more careful process encouraged Alice and myself to spend more time together.

Lastly, British artist and photographer Sarah Jones' painterly photographs are constructed around adolescent emotional experiences, many of which are taken in middle-class, sometimes ornate, domestic spaces. Through casting, staging, and location scouting, Jones creates intriguing tableau photographs that incite viewers to consider the psychological states that often characterize adolescent life. Her carefully crafted images imply tensions between fictionalization and authenticity in contemporary photography, and as characteristics of adolescent identities. ${ }^{49}$ Her participants play a dramatized version of themselves, but also stand in as adolescent archetypes. $^{50}$ Through pose and gesture, Jones' portraits reference the modes of female representation throughout the history of photography. For example, a young figure reclined on a bed with a distant gaze away in her 2003 image, The Guest Room. In much of her work, her participants are presented sitting, in distress, or wallowing in emotional discomfort. Jones' portraits do paint a narrow perspective of adolescence that I have attempted to resist representing in With Alice; however, her ability to fill her stand-alone images with a charged narrative must be acknowledged. It is in this tradition, of storytelling through a singular tableau photograph, that With Alice's portraits of "embodied characters" function most effectively.

\footnotetext{
${ }^{49}$ Charlotte Cotton, The Photograph as Contemporary Art (London: Thames \& Hudson Ltd., 2009), 61.

${ }^{50}$ Ibid.
} 


\section{Conclusion}

My documentary and fine art photographic practice has always examined notions of identity, family, and intergenerational relationships between family members. In With Alice, I recognize and acknowledge the power of reciprocal participation between photographer and subject—in this case cousins - as well as the use of performance through photography, to reveal and explore the complexities of a young woman's identity.

Documentary photography is a creative research practice that depends on the process of imagemaking as the primary mode of inquiry. In the traditions of performance and participatory documentary, With Alice is a form of practice-based research. Using analog portraiture, I present a documentary project in which fact and fiction — staged performances and naturalistic moments — blend together seamlessly, and are of equal importance. This approach has allowed me to create a complex picture of Alice's life, interests, artwork, as well as my own experience of working with her.

With Alice is informed and shaped by dialogues about Alice's experiences, by her performances and artistic practices, and by my own approach to conceptualizing, staging, and producing analog portraits. With Alice is a representation of the knowledge I have gained about her experiences, about the complex participatory relationship between photographer and participant, and about the revelatory power of performance. It is a concrete expression of our participation in the process of creation, through which we gaze both at each other and at ourselves. Alice and I were essentially working next to each other, in parallel with one another throughout this process. With Alice is not 
a collaborative project per se, but rather, documentation produced through a participatory practice.

Explored through three sections of visual materials - portraits of Alice "in process," portraits of her "“"embodied characters"," and the booklet With Alice in Four Parts-Alice's presence in front of the camera, whether posed or more naturalistic, are gestures of sincere and generous participation. She is always aware of my presence. In the "in process" images, Alice allows me to express how I see her — as a young woman, artist, cousin, and adolescent — through my images. In my portraits of her “"“embodied characters"," Alice performs idealized versions of herself, also for my lens, but this time with the intention of exploring her own identity. In these portraits, I participate with her in interpreting the ways in which she sees herself, and how she would like others to perceive her. Finally, With Alice in Four Parts allows my own voice, Alice's paintings, and documentation of her own work, to enter and enrich the picture. This booklet reiterates our participation in the production of With Alice as an essential element to the work, and the potential it holds as a mode through which artists can create truthful and considerate representations of a documentary subject's world.

As I stated in the project description, in a kind of dialogue or conversation, these three elements - the "in process" images, the "embodied character" portraits and the zine — create a dynamic portrait of a mid-adolescent artist, raising important questions about the relationship of the documentary photographer with the participant, and the nature of documentary truth. Truth in documentary photography relies on the photographers' perceptions of their participants' ideas, lives, and circumstances, but also — whether acknowledged or not — on the participation and the 
communication between the image-makers and participants. The documentary truth in this project begins in the moments that Alice and I shared as our relationship developed, captured in my images. The strongest and truest values of my documentary practice are found in the human connections that arise in the photographic process. I believe that documentary photography has the potential to express truth, which, while often ambiguous, is profoundly complex and profoundly human. This is what I aspire to achieve in my photographic practice.

Word Count: 10,533 


\section{Appendix 1. Defense Notes}

Through the process of conceptualizing, producing, and re-examining With Alice after its presentation, I've realized that to create considerate, ethical, and creative documentary work, I had to produce a project that allowed both my participant's voice and my perspectives, to join in conversation with one another.

When I began this program directly after my BFA in photography Concordia University —a program focused almost exclusively on conceptually and aesthetically driven fine art photography work with little mention of documentary practices - I had the perception that to create a documentary work I would need to learn to practice a degree objectivity and to focus on the documentation of Alice's life and voice, rather than my interpretation and representation of it. What I learned eventually, was that I would have to take a much more nuanced approach.

It was actually the process of creating With Alice over this two-year period that reminded me of the richness that can come from allowing yourself as a maker to become an active participant in your work, whether in front or behind the lens. I was reminded that the real gift of documentary for me is the opportunity to develop a genuine caring relationship with my participant. Alice and I's relationship as young female artists working together, and cousins, has shaped, at times uprooted, and then re-shape my final work. Our relationship guided the way this project changed over time. 
In this presentation, I've decided to give you an overview of the ways in which the growing bond between Alice and I have dictated the changes I have made in the conceptualization and presentation of With Alice. I'll give you examples of the difficulties I faced in working with a family member including power dynamics, and the solutions I was able to develop to balance both of our voices in this work.

As I mentioned in my research paper, With Alice began through the intuition that I should start documenting Alice's work. At this time in the fall of 2017 , Alice was entering $9^{\text {th }}$ grade in her first year the Etobecoke School of the Arts, and her work was focused on addressing her feminist perspectives. Upon reflection, what I realized is that it was her experience of adolescence-her self-assuredness, confidence, and self-acceptance — that was so different from my memories of being fifteen that first drew me to Alice.

As the project began, I had the intention of practicing a more observational approach than I had ever done before, but was concerned about traditions in documentary of speaking for and about people and subject, and how documentarians have the ability to manipulate what happens on screen to create the illusion of spontaneity and authenticity to tell the story they want to tell regardless of their subjects' perspectives or realities.

In the early development of With Alice, I was determined to find a way to create work in conversation with my participant and to address my own presence. This is what drew me to the idea of creating a work inspired by the tradition of cinema verité. This approach interested me 
because it allowed filmmakers to share conversations with their participants on screen while simultaneously capturing candid images.

Working from my experience as a portrait photographer, I decided to capture long-take and fixed frame videos of Alice in her everyday life. These were constructed moments that Alice and I crafted together. My intention was to allow the poses that Alice took up in front of my lens to fade over time. During long takes, Alice would often loose her patience, and begin to break her poses. I felt that this approach allowed me to acknowledge my hand as the image maker by constructing a scene, while encouraging Alice to play a part in choosing her poses and allowing her to break them when she grew tired.

An example of this happened at her school, when I was documenting her red tent project that I described in my research paper. In this video, Alice was posed outside of her red tent while I filmed from the inside. A few moments in, when she began receiving texts from her friends, she started to text them back, still holding the pose we had set up, but not realizing that her hands were in my field of vision. These were the kinds of moments I was looking for-where performance met reality.

To narrate these images, I recorded audio interviews that happened off screen between Alice and myself in which she shared her experiences and frustrations as a mid-adolescent artist and feminist young woman — which mostly concerned her feelings about adults she felt weren't listening to her or taking her opinions seriously. 
My plan at this point was to project my video, accompanied by our conversations, within four canvas walls that Alice was going to paint on. This was meant to be an uninterrupted space in which Alice's own perspectives could be expressed, with my support. But in reality, a few months into the project, our audio conversations began to bring up some major concerns in my fall production class.

My first difficulty was trying to prompt Alice to give me a clear definition of what feminism meant to her. In all honesty, I felt pressured by my peers and some faculty to position Alice's own feminist identity within current feminist discourse - and because of this, became dissatisfied by her consistent answer: "Feminism is equal pay and rights for both women and men."

The difficulty for me here was that this definition felt too simplistic. Without judgment, I attempted to bring up contemporary issues of intersectionality and gender binaries, amongst other things, that restrict female-identifying people. But in doing so, I realized that I had created a space that was no longer reciprocal. I was pressuring Alice to address subjects that she had little knowledge about, and didn’t feel confident speaking about.

At the same time, Alice shared with me her experiences of middle school, which were very difficult for her, where she often felt like an outsider. These conversations led us to an important turning point: I realized that a major reason Alice had begun creating feminist artwork was because most of her classmates were doing the same thing, and doing so brought her closer to the other young women in her classes. Because of this, she felt accepted for the first time during her 
adolescence. This was something that I could relate to through my past experiences: the desire to feel part of a community in high school.

This conversation uprooted my work. I felt hesitant about presenting Alice as a feminist artist, which began to feel restrictive. I refused to box her in, and wanted to follow her journey. With our growing bond as cousins and as young artists, I became protective over Alice, and the ways in which viewers may make unfair judgments on her notions of feminism. I was particularly concerned by the moments in which Alice began to use the terms feminist identity and feminine identity interchangeably. Alice was also experiencing this tension at school. When she would present her artwork, her peers would challenge her feminine appearance as contradictory to how they thought a feminist should look.

These challenges, for both Alice and I, were the catalyst to the complete restructuring of With Alice during the summer of 2018. I felt the need to strip my work of explicit terminology, and focus on building a portrait young woman developing her artistic practice.

During this time, Alice was also becoming less focused on feminist discourse in her work, and began exploring her identity by painting her character portraits and photographing herself embodying these women. Alice was fully embracing herself, for herself, which to me is an implicit feminist act in itself.

The first iteration of With Alice as a video project didn't feel right anymore for these reasons: 
- I was causing Alice's responses to my questions to become disingenuous because she could sense that I was frustrated by her answers

- Alice had expressed to me that she wanted to move away from defining her work as strictly feminist because it felt restrictive

- I was also concerned that my video instillation would provoke unfair criticism about Alice's feminist perspective, which both of us had actually experienced in our schools

So as Alice shifted her artistic practice from feminism to self-exploration, I decided to shift With Alice. I asked myself: how is she exploring herself and how can I present that process through my images? My solution was to return to portrait photography. I found that the most effective and respectful way to create a portrait of Alice was to allow myself to create a representation of her process. This allowed me to become more creative while respecting her practice.

To me this exhibition is a genuine reflection of my instincts, led by our deepening bond, balancing both of our perspectives together. I've spoken in depth about the visual elements of this exhibition in my research paper, but I'll briefly touch upon some aspects that I didn't mention.

This first wall is composed of images of Alice "in process." These are a continuation of what I was doing in my first videos of Alice: trying to capture her everyday life through posed reality. Organized in sequences of triptychs, diptychs, and stand-alone images, these are really glimpses of important moments that I shared with Alice through the process of creating this work. They 
are reflections of the memories I keep about this process that I don't share with my viewers, but only hold and share with Alice.

All in all, these images are nostalgic for me. They speak to our relationship and to our participation with one another. What they do in this space for viewers hung opposite my portraits of embodied characters is provide a multifaceted portrait of Alice. She is a performer, a glamorous young woman, an adolescent with a messy room, with a pet bird, and who uses her iPhone camera to apply her makeup at school. She is who she is.

This takes me to my portraits of Alice's embodied characters. Recently, she's shared with me that her performances never really stop anymore. She says that all of these women she paints and performs have become genuine, and irreversibly, part of who she is. Her real life and passion for performance have blended together. Alice takes her own images of her characters, but on this wall, I showcase my interpretations of these facets of Alice based on the qualities each embodiment brings out in her.

I spoke in depth about these portraits in my research paper, so I'm now going to briefly address the zine I created as the third element of my instillation. With Alice in Four Parts is the piece that ties everything together and ties up loose ends.

By narrating the entire development of With Alice from film to photography, I make it clear that an important part of the project has been the process of creation and my determination to follow Alice's progression, rather than pigeon-holing her practice. I am also able to bring Alice's own 
paintings into the space to inform the source of my character portraits. Through the zine, I was also able to create a clear distinctions between the photographs Alice takes of her embodied characters and my own portraits. This is was my way of addressing the importance of claiming authorship in the act of participation

At the end of the first act of this project, I feel like I've really established who I am as a photographer, and how I would like to continue to produce documentary work.

One of my principle sources for the production of With Alice has been Alessandra Sanguinetti's project, The Adventures of Guille and Belinda and the Enigmatic Meaning of Their Dreams. I mentioned this work in my research paper. This four-year-long project capturing images that represent her two cousins imaginary worlds blending with reality. In With Alice, I've tried my best to create images that do something similar: create a portrait of who Alice is, and the women she fictionalizes and embodies as her own icons. In her world, fact and fiction blend together. She is at once herself, an adolescent female artist, and an amalgamation of the characters she has dreamt to be.

As I think about how I'll continue this project, I imagine a book reminiscent of Larry Sultan's, Pictures from Home. What's so powerful about Sultan's book is his writing, where his family members' voices that he recorded separately are combined together to describes their family stories and collective memories. This is a narrative sewn together through multiple perspectives. 
I see same potential in my project with Alice. We share a mutual understanding of who we are as individual artists, and also as participants with one another. For the next chapter of this project, I can imagine a written narrative focused on Alice's, and my own, first person experiences of the moments I photograph. I will be working now in the direction of a more long-form written element, with the final publication as a book.

From the very beginning, I was drawn to photography by a desire to create a space, through the process of taking an image, in which I could connect, or reconnect, with my participants. This is what the final instillation of With Alice does. It's a reflection of our participation with one another and of my respect for our relationship. With Alice is far from an objective documentation, but rather, a project that has developed through our growing relationship, through our desire to participate together, and through my own presentation of Alice's world through photography, sequencing, and the zine.

Through my work, I try my best to resist notions of absolute truth and objectivity. In my opinion, compelling stories reflect multidimensional perspectives, where not only one truth is implied. Truth to me is really brought out through the interactions and relationships shared between participants and makers. This notion of truth is my new starting point, from which I'll begin the next chapter of my work with Alice. 


\section{Bibliography}

Akerman, Chantal. From the Other Side. Directed by Chantal Akerman. 2012. https://www.amazon.com/Other-Side-Englishsubtitled/dp/B007WZF4XO/ref=sr_1_sc_1? s=instantvideo\&ie=UTF8\&qid $=1444147875 \&$ sr $=1-1$-spell $\&$ keywords $=$ chantal+ackerman Artnet. "Jeff Wall.” Artnet, http://www.artnet.com/artists/jeff-wall/.

Baden, Evan. "Under the Influence." Evan Baden. 2013. http://www.evanbaden.com/under-theinfluence-\%E2\%80\%93-201213.html.

Bae, Michelle. "Interrogating Girl Power: Girlhood, Popular Media, and Postfeminism." In Visual Arts Research, vol. 37, no. 2. Illinois: University of Illinois Press, 2001, pp. 28-40.

Barrett, Anne E., and Naiman-Sessions, Miriam. "'It's Our Turn to Play': Performance of Girlhood as a Collective Response to Gendered Ageism.” In Ageing and Society, vol. 36, no. 4. Cambridge: Cambridge University Press, 2016, pp. 764-784.

Brown, Lyn Mikel. Meeting at the Crossroads: Women's Psychology and Girls' Development. New York: Ballantine Books, 1993.

Butler, Judith. Gender Trouble: Feminism and the Subversion of Identity. New York: Routledge, 1990.

Caruth, Cathy. Trauma Explorations in Memory. Baltimore: John Hopkins University Press, 1995.

Clifton, Lucille. The Book of Light. Washington: Copper Canyon Press, 1993.

Collins, Petra. Coming of Age. New York: Rizzoli, 2017.

Cotton, Charlotte. The Photograph as Contemporary Art. London: Thames \& Hudson Ltd., 2009.

Davis, Heather. Desire Change: Contemporary Feminist Art in Canada. McGill-Queen's University Press and Mentoring Artists for Women's Art, 2017.

De Jong, Mea. If Mama Ain't Happy, Nobody's Happy. Directed by Mea de Jong. 2014. https://vimeo.com/100880350

Douglas, Susan. Enlightened Sexism: The Seductive Message That Feminism's Work Is Done. New York: Times Books, 2010.

Driscoll, Catherine. Girls: Feminine Adolescence in Popular Culture and Cultural Theory. New York: Columbia University Press, 2002.

Emin, Tracey. Everyone I Have Ever Slept With 1963-1995. Installation: appliqued tent, mattress, and light. 1995.

http://www.traceyeminstudio.com/artworks/1995/02/everyone-i-have-ever-slept-with1963-1995-1995-2/

Erikson, Eric. Childhood and Society. New York: W.W. Norton and Co., 1993.

Fivush, Robyn, and Zaman, Widaad. "Gendered Narrative Voices: Sociocultural and Feminist Approaches to Emerging Identity in Childhood and Adolescence." In The Oxford Handbook of Identity and Development. New York: Oxford University Press, 2015, pp. 33-52.

Friedan, Betty. The Feminine Mystique. New York: W. W. Norton and Co., 1963.

Greenfield, Lauren. Girl Culture. San Francisco: Chronicle Books, 2002.

Grindon, Leger. "Q\&A: Poetics of the Documentary Film Interview." Velvet Light Trap 60 (2007): 4-12. 
Guerrilla Girls. "Guerrilla Girls.” https://www.guerrillagirls.com.

Guggenheim. "Helen Van Meene." Guggenheim Museum.

https://www.guggenheim.org/artwork/10235.

Hentges, Sarah. Pictures of Girlhood: Modern Female Adolescence on Film. Jefferson:

McFarland, 2006.

Hooks, Bell. Feminism is for Everybody: Passionate Politics. New York: South End

Press, 2000.

Jiwani, Jasmin, Mitchell, Claudia, and Steenbergen, Candis. Girlhood: Redefining the

Limits. Montreal: Black Rose Books, 2006.

Lake, Suzy. "Suzy Lake on the Politics of Gender, the Body, and Identity." Lecture presented at ArtsEverywhere, Ontario, 2017.

Lamb, Sharon, and Peterson, Zoë D. “Adolescent Girls' Sexual Empowerment: Two

Feminists Explore the Concept.” In Sex Roles, vol. 66, no. 11-12. Springer US, 2012,

pp. 703-712. Accessed November 5, 2017, https://journals-scholarsportal-

info.ezproxy.lib.ryerson.ca/pdf/03600025/v66i11-12/703_agsetfetc.xml

Lanzmann, Claude. Shoah. Documentary Film. Directed by Claude Lanzmann. 1985.

New York: New Yorker Video, 2003. DVD.

Lee Jin, Hye, and Wen, Huike. "Where the Girls Are in the Age of New Sexism: An Interview With Susan Douglas.” In Journal of Communication Inquiry, vol. 33, no. 2.

California: Sage Publications, 2009, pp. 93-103.

Looft, Ruxandra. "\#Girlgaze: photography, fourth wave feminism, and social media advocacy." Continuum: Journal of Media \& Cultural Studies 31, no.6 (2017): 892-902

Magowan, Isabel. Cygnets. 2017. Photography. New York: Isabel Magowan. Accessed 2

Nov. 2017. https://www.isabelmagowan.com/PHOTOGRAPHS/Cygnets/1/caption

Mark Gabrille, Lisa. Wack! Art and the Feminist Revolution. Los Angeles: The Museum of Contemporary Art, 2007.

Marian Goodman Gallery. "Rineke Dijkstra." Mariam Goodman Gallery. https://www.mariangoodman.com/artists/rineke-dijkstra.

Marshall, Julia. "Visual Images in Practice-Based Research." Studies in Art Education 49, no.1 (2007): 23-41.

MET. "Almersia, Leidschendam, The Netherlands." The Metropolitan Museum of Art. https://www.metmuseum.org/art/collection/search/294428.

MoMA. "Cindy Sherman: Untitled Film Stills 1977-1980." Museum of Modern Art. https://www.moma.org/learn/moma_learning/cindy-sherman-untitled-film-stills-1977-80/.

Morin Edgar, and Rouche, Jean. Chronique d'un été. Directed by Edgard Morin and Jean Rouche. 1961. https://vimeo.com/54909410

Mulvey, Laura. "Visual Pleasures and Narrative Cinema." In Film Theory and Criticism: Introductory Readings. Edited by Leo Braudy and Marshall Cohen. New York: Oxford UP, 1999: 833-844.

Munro, Ealasaid. "Feminism: A Fouth Wave?” Political Insight 4, no.2 (2013): 22-25.

Newman, Shirley, and Glennis Stephenson. ReImagining Women: Representations of Women in Culture. Toronto: University of Toronto Press, 1993.

Nichols, Bill. Introduction to Documentary. Bloomington: Indiana University Press, 2001.

Nichols, Bill. "Reenactment and the Fantasmic Subject." Critical Inquiry 35, no.1 (2008): 72-89. 
O'Hagan, Sean. "Pictures from Home by Larry Sultan review: When Mom and Dad Lived the Dream." The Observer, 2017: 39, Error! Hyperlink reference not valid.

Oursler, Tony. The Poetics Project. Installation. 2013.

https://www.tonyoursler.space/the-poetics-project/0o9okoctmhs5setkambpg2j19qzhwx

Raymond, Calire. Women Photographers and Feminist Aesthetics. New York: Routledge, 2017.

Rist, Pipilotti. Himalaya's Sister's Living Room. Video installation with ten projectors, wallpapered wood panels, furniture, toys, food, books, clothing, and various found object, with sound. 2000. https://www.guggenheim.org/artwork/13964

Rist, Pipilotti. Sip My Ocean. Single-channel video installation, shown using two projects with sound, 8 min. 1996. https://www.guggenheim.org/artwork/5208

Rogers, Beth. Adolescent Girlhood and Literacy Culture at the Fin de Siècle: Daughters of Today. New York: Springer Nature, 2016.

Romig, Rollo. "Off The Shelf: The Adventures of Guille and Belinda." The New Yorker. June 18, 2010. https://www.newyorker.com/culture/photo-booth/off-the-shelf-the-adventures-ofguille-and-belinda.

Rosler, Martha. Monumental Garage Sale. Installation. 1973. http://www.martharosler.net/projects/garagesale1.html

Sayers, Janet. “Teenage Dreams: Feminism, Psychoanalysis, and Adolescence.” In Signs. Chicago: University of Chicago Press, 2000, pp. 817-839.

Sjöblom, Yvonne. "Leaving Home Early: Passing from Girlhood to Womanhood." In Child and Adolescent Social Work Journal, vol. 23, no.4. Springer US, 2006, pp. $432-$ 457. Accessed November 1, 2017, https://journals-scholarsportal-8 info.ezproxy.lib.ryerson.ca/pdf/07380151/v23i0004/432_lhepfgtw.xml

Sontag, Susan. "Photography Within the Humanities." In The Photography Reader, edited by Liz Wells, 59-66. New York: Routledge, 2003.

Sullivan, Graeme. "Research Acts in Art Practice." Studies in Art Education 48, no.1 (2006): 12-35.

Sultan, Larry. "Pictures from Home: Statement/ History." Larry Sultan. http://larrysultan.com/gallery/pictures-from-home/.

Tolman, Deborah. "Female Adolescents, Sexual Empowerment and Desire: Discourse of Gender Inequity." In Sex Roles, vol. 66, no. 11-12. Springer US, 2012, pp. 746-757. Accessed November 5, 2017, https://journals-scholarsportalinfo.ezproxy.lib.ryerson.ca/pdf/03600025/v66i11- 12/746_faseadamdogi.xml

Uhlyarik, Georgiana. Introducing Suzy Lake. London: Black Dog Publishing, 2015.

Van Meene, Helen. Portraits. New York: Aperture, 2005.

Washburn, Phoebe. Regulated Fool's Milk Meadow. Installation: wood, glass, seeds, water, wire mesh, and plants. 2007. https://www.guggenheim.org/artwork/21047

Waugh, Thomas. The Right to Play Oneself: Looking Back on Documentary Film. Minnesota: University of Minnesota Press, 2011.

Wolf, Naomi. The Beauty Myth. New York: Harper Perennial, 1990.

Women in Photography New York. "Alessandra Sanguinetti." WIPNY, https://www.wipnyc.org/past/2017215-2.

Zeilinger, Julie. A Little F'D UP: Why Feminism Is Not a Dirty Word. Berkley: Seal Press, 2012. 